\title{
First Report of Heterotermes longiceps (Blattodea: Rhinotermitidae) Termite in Teak Plantations
}

\author{
Leonardo Leite Fialho-Junior ${ }^{1}$ (D), Diego Arcanjo Nascimento² (D), \\ Isabel Carolina de Lima Santos ${ }^{1}$ (D), Otávio Peres-Filho ${ }^{3}$ (D), \\ Alexandre dos Santos ${ }^{1}$ \\ ${ }^{1}$ Instituto Federal de Educação, Ciência e Tecnologia de Mato Grosso - IFMT, Cáceres/MT, Brasil \\ ${ }^{2}$ Universidade Estadual Paulista "Júlio de Mesquita Filho" - UNESP, Botucatu/SP, Brasil \\ ${ }^{3}$ Universidade Federal de Mato Grosso - UFMT, Cuiabá/MT, Brasil
}

\begin{abstract}
Heterotermes longiceps termites was observed causing injuries in Tectona grandis plants in a forest plantation in Cáceres, Mato Grosso, Brazil. H. longiceps caused galleries below the bark, at the heartwood-sapwood interface, from the beginning of the root until approximately $1 \mathrm{~m}$ height tall and very infested plants has died. This is the first report of $H$. longiceps damage in teak in Brazil.
\end{abstract}

Keywords: forest entomology, forest protection, Tectona grandis. 
Teak, Tectona grandis, is a forest species native to southwestern Asia, between parallels $20^{\circ}$ and $10^{\circ} \mathrm{N}$ (Hansen et al., 2014; Deb et al., 2017), which has been gaining each more space in the world forest scene due to the high quality and resistant wood, used for the manufacture of fine furniture, shipbuilding and civil construction (Miranda et al., 2011; Moya et al., 2014). Currently, countries with the largest teak areas in the world are India and Indonesia, but countries in South and Central America such as Brazil, Ecuador, and Panama, and African countries such as Ghana and Nigeria, are in full expansion of their planting areas (Kollert \& Cherubini, 2012).

The first teak plantations in Brazil occurred in the Mato Grosso state, in the decade of 1970 (Assis \& Resende, 2011). According to IBÁ (2017), in 2016 there was a planted area of 87,502 hectares in the country.

Cultivated forests become an abundant resource for insects feeding, causing some species to rise to pest level (Kulkarni et al., 2009; Nascimento et al., 2016). The termites attack on seedlings or live trees can destroy the root system and cause the death of plants (Junqueira et al., 2008; Leitão-Lima et al., 2014), support the development of pathogens (Kirton \& Cheng, 2007), or reduce the wood production (Hadi et al., 2010). However, most of the termite fauna present in the plantations are represented by beneficial species with a key role in the forest ecosystem (Jouquet et al., 2011).

Among the species of economic importance are heartwood termites, which attack the trees in cultivated forests, such as Coptotermes testaceus (Linnaeus, 1758), Cylindrotermes sp. and Heterotermes spp. (Constantino, 2002). Although, these species have reduced importance when compared to termites of seedlings of the genera

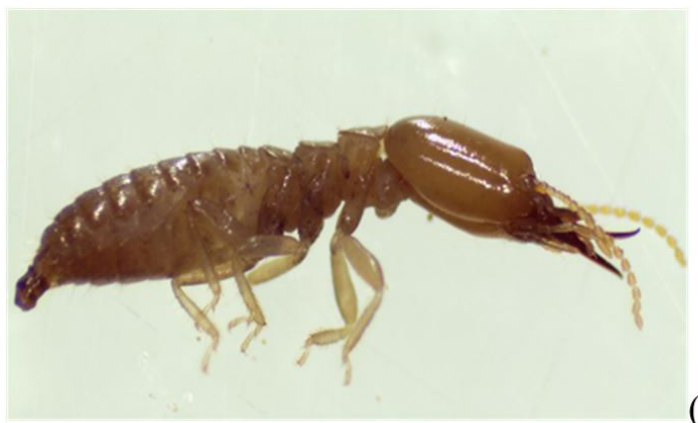

(A)

Syntermes and Cornitermes (Wilcken et al., 2002; Santos et al., 2015).

In a study of termites associated with the degradation of Tectona grandis wood in Sinop, Mato Grosso state, Brazil, were observed two different species of Anoplotermes genus, Coptotermes testaceus, Cyrilliotermes angulariceps and Embiratermes neotenicus (Corassa et al., 2014). Teak wood showed a natural resistance to Coptotermes formosanus termites in bioassays in New Orleans, LA (Cornelius \& Osbrink, 2015).

Heterotermes tenuis and $H$. longiceps termites are the most abundant in South America, with wide geographical distribution and reported as agricultural pests (Constantino, 2002). In this context, the objective of this work was to report the first occurrence of Heterotermes longiceps (Snyder, 1924) termite and describe the injuries promotes in clonal commercial teak plantations.

Trees in a commercial plantation were found with $20 \%$ of termite infestation in the trunk and below the bark, in 100 hectares of teak plantation in Cáceres municipality $\left(16^{\circ} 04^{\prime} 14^{\prime \prime} \mathrm{S}, 57^{\circ} 40^{\prime} 44^{\prime \prime} \mathrm{W}\right.$ and altitude of 117 m), Mato Grosso state, Brazil, in September 2015.

The injuries promoted by these organisms to the plants were photographed. The termites of the caste of the soldiers were collected in the plants and preserved in $80 \%$ alcohol. They were sent to the Laboratório de Fitossanidade (FitLab) of the Instituto Federal de Mato Grosso (IFMT) - Campus Cáceres, Mato Grosso state, Brazil, where it was screened with a stereoscopic microscope (40x), photographed and identified.

The specimens were identified as Heterotermes longiceps (Blattodea: Rhinotermitidae) (Figure 1A and B). The injuries observed were the formation of galleries up the bark and below the bark, in the interface

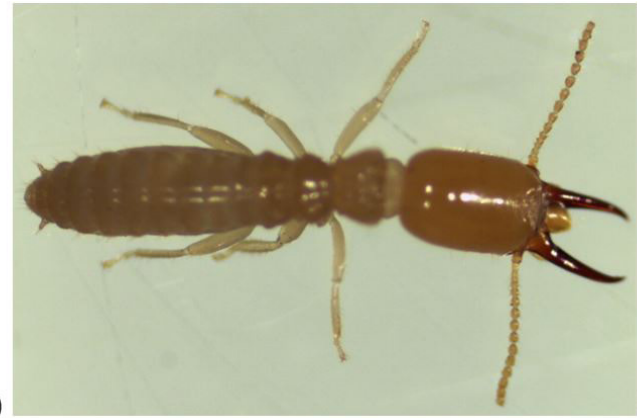

Figure 1. Soldier of Heterotermes longiceps. (A) Lateral region; (B) Dorsal region. 
bark-sapwood (Figures $2 \mathrm{~A}$ and $\mathrm{B}$ ), from the beginning of the root to approximately $1 \mathrm{~m}$ tall. A larger number of galleries were observed in the stem (Figure $2 \mathrm{~A}$ ), decreasing as they ascended the trunk (Figure 2B). There were also galleries in the center of the heartwood in one individual (Figure $3 \mathrm{~A}$ ) and was observed the death of two trees (Figure 3B).

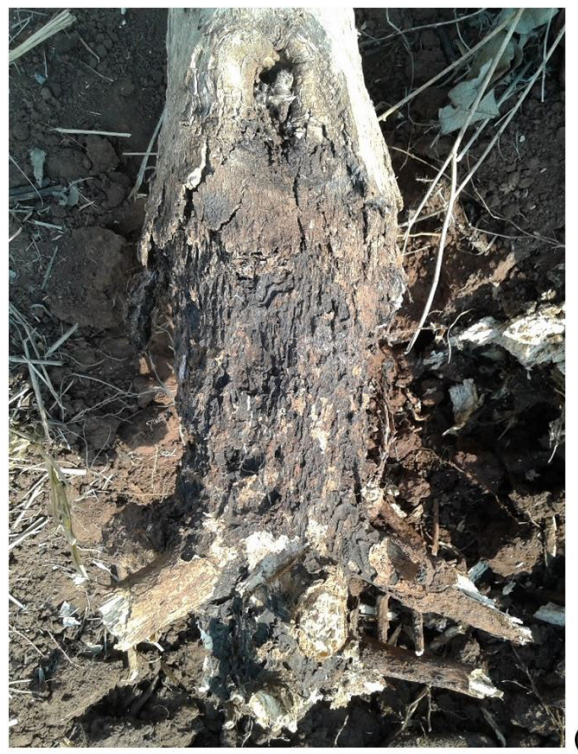

(A)

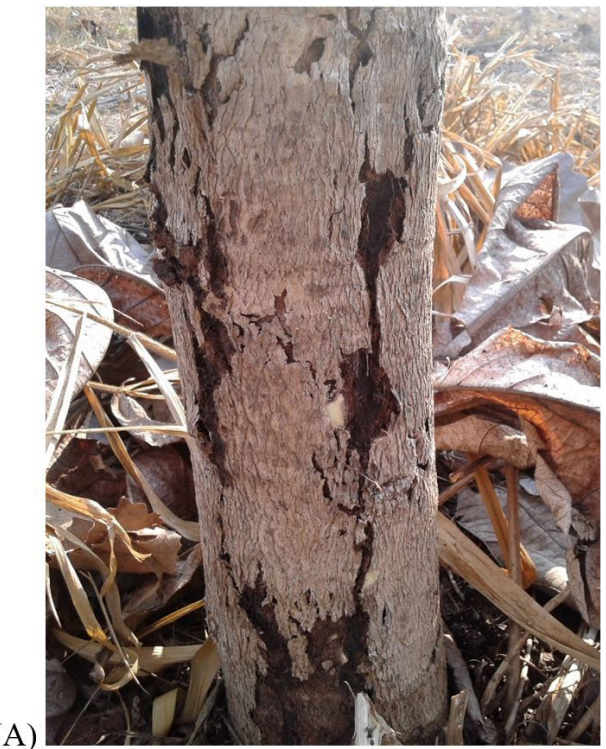

(B)

Figure 2. Injuries caused by Heterotermes longiceps. (A) Termite galleries on the bark; (B) Termite galleries below the bark.
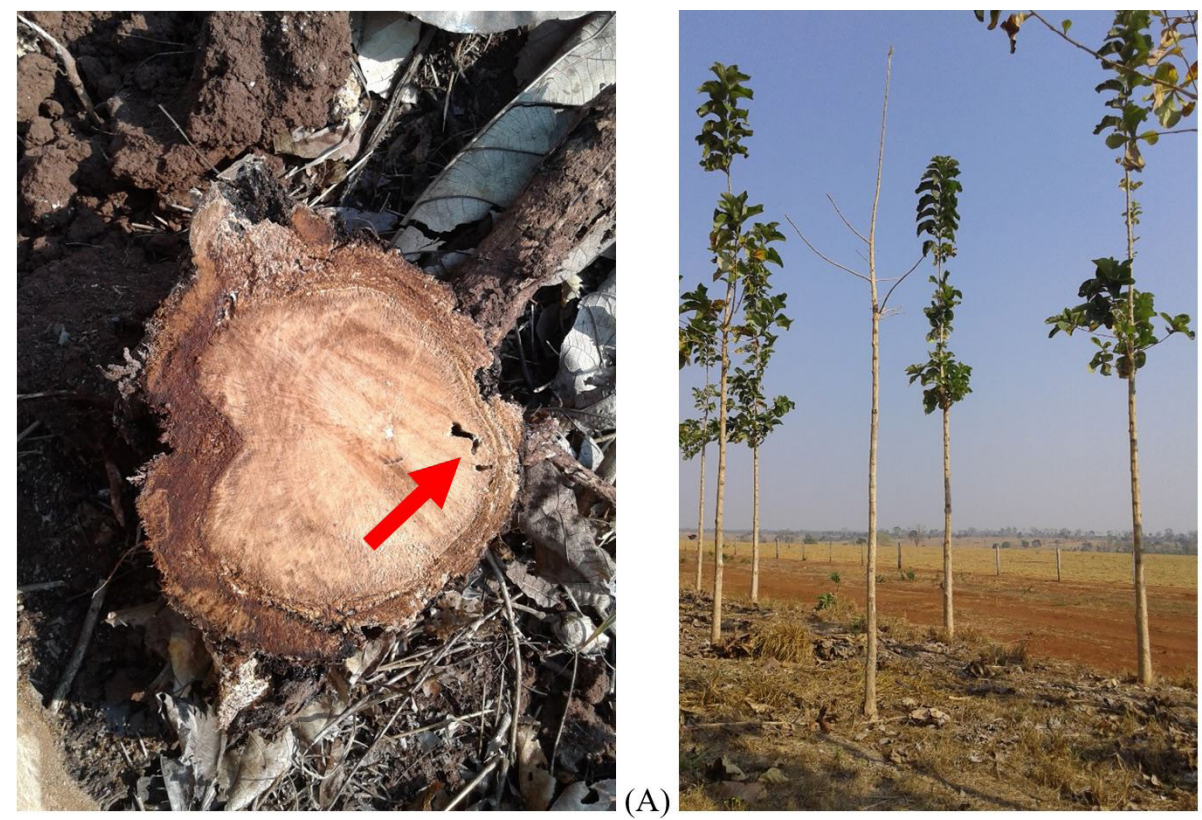

(B)

Figure 3. (A) Damage caused by Heterotermes longiceps in the sapwood of the plant; (B) Dead plant by termite attack in the field. 
great losses to the forest production, making the commercialization of the wood impossible or even causing the death of the trees, besides being associated with the occurrence of canker caused by Cryphonectria cubensis (Raetano et al., 1997).

Species of the genus Heterotermes have a wide world distribution, occurring in all tropical and subtropical regions and areas. Teak plantations are increasingly expanding in tropical regions (Kollert \& Cherubini, 2012), which may promote an increase in the occurrence of encounters between these two species.

The present study reports the occurrence and characterizes the injuries of the termite Heterotermes longiceps (Blattodea: Rhinotermitidae) on commercial teak plantations (Tectona grandis) in Brazil.

\section{SUBMISSION STATUS}

Received: 15 aug., 2018

Accepted: 4 feb., 2019

\section{CORRESPONDENCE TO}

\section{Alexandre dos Santos}

Instituto Federal de Educação, Ciência e Tecnologia de Mato Grosso - IFMT, Avenida dos Ramires, s/n, Distrito Industrial, CP 244, CEP 78200-000, Cáceres, MT, Brasil e-mail: alexandre.santos@cas.ifmt.edu.br

\section{REFERENCES}

Assis TR, Resende MDV. Genetic improvement of forest tree species. Crop Breeding and Applied Biotechnology 2011; 11(spe): 44-49. http://dx.doi.org/10.1590/S198470332011000500007.

Constantino R. The pest termites of South America: taxonomy, distribution and status. Journal of Applied Entomology 2002; 126(7): 355-365. http://dx.doi. org/10.1046/j.1439-0418.2002.00670.x.

Corassa JN, Pires EM, Andrade VR No, Tariga TC. Témitas associados à degradação de cinco espécies florestais em campo de apodrecimento. Floresta e Ambiente 2014; 21(1): 78-84. http://dx.doi.org/10.4322/floram.2014.014.

Cornelius ML, Osbrink WLA. Natural resistance of exotic wood species to the Formosan subterranean termite (Isoptera: rhinotermitidae). International Biodeterioration \& Biodegradation 2015; 101: 8-11. http://dx.doi.org/10.1016/j. ibiod.2015.03.016.
Deb JC, Phinn S, Butt N, McAlpine CA. Climatic-induced shifts in the distribution of teak (Tectona grandis) in Tropical Asia: implications for forest management and planning. Environmental Management 2017; 60(3): 422-435. http:// dx.doi.org/10.1007/s00267-017-0884-6. PMid:28474209.

Hadi YS, Nurhayati T, Yamamoto JH, Kamiya N. Smoked wood resistance against termite. Journal of Tropical Forest Science 2010; 22(2): 127-132.

Hansen OK, Changtragoon S, Ponoy B, Kjær ED, Minn Y, Finkeldey R et al. Genetic resources of teak (Tectona grandis Linn. f.) strong genetic structure among natural populations. Tree Genetics \& Genomes 2014; 11(1): 1-16.

Indústria Brasileira de Árvores - IBÁ. Relatório anual 2017: ano base 2016. Brasília: IBÁ; 2017.

Jouquet P, Traoré S, Choosai C, Hartmann C, Bignell D. Influence of termites on ecosystem functioning: ecosystem services provided by termites. European Journal of Soil Biology 2011; 47(4): 215-222.

Junqueira LK, Diehl E, Berti EB Fo. Termites in eucalyptus forest plantations and forest remnants: an ecological approach. Bioikos 2008; 22(1): 3-14.

Kirton LG, Cheng S. Ring-barking and root debarking od dipterocarp samplings by termites in an enrichment planting site in Malaysia. Journal of Tropical Forest Science 2007; 19(2): 67-72.

Kollert W, Cherubini L. Teak resources and market assessment 2010 [online]. Rome: FAO; 2012. (FAO Planted Forests and Trees Working Paper; no. FP/47/E) [cited 2016 Feb 1]. Available from: http://www.fao.org/forestry/ plantedforests/67508@170537/en/

Kulkarni N, Paunikar S, Joshi KC, Rogers J. White grubs, Holotrichia rustica and Holotrichia mucida (Coleoptera: Scarabaeidae) as pests of teak (Tectona grandis L. f.) seedlings. Insect Science 2009; 16(6): 519-525. http:// dx.doi.org/10.1111/j.1744-7917.2009.01289.x.

Leitão-Lima PS, Lima EV, Wilcken CF, Pereira LG. Atração de Cornitermes cumulans Kollar, 1932 (Isoptera: Termitidae) à raiz de eucalipto e ao substrato para produção das mudas. Revista de Agricultura 2014; 89(3): 187-198.

Melo ACS, Bandeira AG. Consumo de madeira por Heterotermes sulcatus (Isoptera: Rhinotermitidae) em ecossistema de Caatinga no nordeste do Brasil. Oecologia Brasiliensis 2007; 11(3): 350-355. http://dx.doi.org/10.4257/ oeco.2007.1103.05.

Miranda I, Sousa V, Pereira H. Wood properties of teak (Tectona grandis) from a mature unmanaged stand in East Timor. Journal of Wood Science 2011; 57(3): 171-178. http://dx.doi.org/10.1007/s10086-010-1164-8.

Moya R, Bond B, Quesada H. A review of heartwood properties of Tectona grandis trees from fast-growth plantations. Wood Science and Technology 2014; 48(2): 411-433. http://dx.doi.org/10.1007/s00226-014-0618-3. 
Nascimento DA, Anunciação RM Jr, Arnhold A, Ferraz AC Fo, Santos A, Zanuncio JC. Expert system for identification of economically important insect pests in commercial teak plantations. Computers and Electronics in Agriculture 2016; 121:368-373. http://dx.doi.org/10.1016/j.compag.2015.12.024.

Raetano CG, Wilcken CF, Crocomo WB. Controle de cupins em florestas de eucalipto com o inseticida fipronil (Regent 20G) aplicado em cobertura. Revista Árvore 1997; 21(2): 289-293.

Santos A, Santos JC, Cardoso JR, Serrão JE, Zanuncio JC, Zanetti R. Sampling of subterranean termites Syntermes spp. (Isoptera: Termitidae) in a eucalyptus plantation using point process and geostatistics. Precision Agriculture 2015; 17(4): 421-433. http://dx.doi.org/10.1007/s11119015-9428-3.

Shanbhag R, Sundararaj R. Physical and chemical properties of some imported woods and their degradation by termites. Journal of Insect Science 2013; 13: 63. http:// dx.doi.org/10.1673/031.013.6301. PMid:23906349.

Wilcken CF, Raetano CG, Forti LC. Termite pests in Eucalyptus forests in Brasil. Sociobiology 2002; 40(1): 179-190. 